\title{
Short communication: Genetic trends of milk yield under heat stress for US Holsteins
}

\author{
I. Aguilar, ${ }^{*} \dagger^{1}$ I. Misztal, ${ }^{*}$ and S. Tsuruta* \\ *Animal and Dairy Science Department, University of Georgia, Athens 30602 \\ †Instituto Nacional de Investigación Agropecuaria, Las Brujas 90200, Uruguay
}

\begin{abstract}
Data included 90,242,799 test-day milk records from $5,402,484$ Holstein cows in the first 3 parities and $9,326,754$ animals in the pedigree. Additionally, daily temperature-humidity indexes from 202 weather stations were available. Analyses were done by a random regression model in which each parity was treated as a separate trait and that accounted for heat stress. The fixed effects included herd test-day, age at calving, milking frequency, and days in milk classes. Random effects included additive genetic, permanent environment, and herd-year effects, all fit as random regressions. Five covariates in the random regressions included linear splines with 4 knots at 5, 50, 200, and 305 DIM and a function of a temperature-humidity index (THI). Mixed model equations were solved by using an iteration on data approach with a preconditioned conjugate gradient algorithm. Genetic trends for daily milk yield in absence of heat stress (intercept) were $0.140 \mathrm{~kg} / \mathrm{yr}$, $0.172 \mathrm{~kg} / \mathrm{yr}$, and $0.168 \mathrm{~kg} / \mathrm{yr}$ for the first, second, and third parity, respectively. Genetic trends for decline of milk yield at temperature of $5^{\circ} \mathrm{C}$ THI over the threshold of sensitivity to heat stress were $-0.002 \mathrm{~kg} / \mathrm{yr},-0.035$ $\mathrm{kg} / \mathrm{yr}$, and $-0.038 \mathrm{~kg} / \mathrm{yr}$, for first, second, and third parity, respectively. Genetic profiles were created by contrasting the 100 most and 100 least heat-tolerant bulls for the official proofs. The most heat-tolerant bulls transmitted lower production and dairy form but higher fertility, productive life, and type, especially udder and locomotion traits. In later parities, the type advantages were smaller. Test-day records capture only a fraction of information due to heat stress, and the real trends for heat stress may be stronger. Studies on heat stress for production should include records on later parities.
\end{abstract}

Key words: heat stress, genetic trend, dairy cattle

Received September 21, 2009.

Accepted December 4, 2009.

${ }^{1}$ Corresponding author: iaguilar@inia.org.uy
Heat stress in dairy cattle affects production traits (Maust et al., 1972; Fuquay, 1981; Bryant et al., 2007) and reproduction (Ravagnolo and Misztal, 2002; Jordan, 2003; Garcia-Ispierto et al., 2007). Economic losses due to heat stress in the US dairy industry are estimated to be between $\$ 897$ and $\$ 1,500$ million per year (St-Pierre et al., 2003). Different approaches are used to manage heat stress in dairy cattle including cooling, shading, and nutrition (Kadzere et al., 2002; West, 2003).

Ravagnolo and Misztal (2000) looked at the genetic components of heat stress using a model with a regression on a function of a temperature-humidity index (THI). They found substantial genetic variability for heat tolerance of production traits. Another study by Ravagnolo and Misztal (2002) found the same for nonreturn rate. In both studies, the genetic correlation between performance in temperate conditions and the rate of decline at higher temperatures was negative.

Bohmanova et al. (2005) carried out a national genetic evaluation for heat tolerance for milk using data from first-parity US Holstein cows. Breeding values were calculated for approximately 10 million animals using a repeatability test-day model with a random regression on THI. Bulls with higher heat tolerance had daughters with lower milk yield, higher content of milk solids, more robust bodies, better udders, longer productive lives, and higher daughter pregnancy rates.

Aguilar et al. (2009a) extended the model of Ravagnolo and Misztal (2000) to 3 parities treated as correlated traits and a random regression model with linear splines and 4 knots. They found that the genetic variance associated with heat stress for production approximately doubles from first to second parity and again doubles from second to third parity. Thus, cows become more sensitive to heat stress with increasing parities. The increasing sensitivity to heat stress can be one reason for deterioration on productive life especially under challenging conditions.

Pszczola et al. (2009) looked at trends of days open also using a model that indirectly accounted for heat stress. Although trends for days open were slightly positive in colder seasons, the rate of decline under 
Table 1. Summary of the data used in the genetic evaluation

\begin{tabular}{lrrr}
\hline & \multicolumn{3}{c}{ Lactation } \\
\cline { 2 - 4 } Item & 1 & 2 & 3 \\
\hline Test-day records (n) & $49,351,124$ & $26,856,302$ & $14,035,373$ \\
Cows (n) & $5,402,484$ & $2,932,915$ & $1,537,959$ \\
Herd-test days (n) & $2,603,783$ & $2,153,285$ & $1,749,619$ \\
Milk yield (kg) & 29.5 & 34.6 & 36.2 \\
Milk SD (kg) & 7.3 & 9.9 & \\
Animals in pedigree (n) & & $9,326,754$ & \\
\hline
\end{tabular}

hot conditions was negative. This indicated increased sensitivity to heat stress over time.

The objectives of this study were to investigate the genetic trends for milk yield heat tolerance for each of the first 3 parities separately and to create PTA profiles for top bulls for heat tolerance. Test-day (TD) records of US Holsteins that included the first 3 parities between 1993 and 2004 were obtained from the Animal Improvement Programs Laboratory, ARS, USDA (Beltsville, MD). Lactation records were required to have only 2 or 3 milkings per day and at least $4 \mathrm{TD}$, with the first TD at $<75$ DIM, and TD between 5 and 305 DIM. Calving ages were restricted to 18 to 35 mo for parity 1, 28 to $49 \mathrm{mo}$ for parity 2, and 40 to 63 mo for parity 3 . Cows were also required to have the first lactation recorded. A 3-generation pedigree file of 9,326,754 animals was extracted from 5,402,484 cows with records. A summary of the data set is presented in Table 1.

Weather data were taken from 202 public weather stations. Hourly THI (NOAA, 1976) was calculated as proposed by Ravagnolo et al. (2000):

$$
\begin{aligned}
& \operatorname{THI}(t, r h)=(1.8 \times t+32)-(0.55-0.0055 \times r h) \\
& \times(1.8 \times t-26),
\end{aligned}
$$

where $t$ is temperature in degrees Celsius, and $r h$ is relative humidity as a percentage. Herds were matched to the closest weather station, and TD records were assigned to the average daily THI of the third day before the TD. This 3-d lag was suggested in previous studies by Bohmanova et al. (2008).

A function of THI $[\varphi(T H I)]$ was created as follows:

$$
\varphi(T H I)=\left\{\begin{array}{cc}
\text { if } T H I \leq T H I_{\text {Threshold }} & 0 \\
\text { if } T H I>T H I_{\text {Threshold }} & T H I-T H I_{\text {Threshold }}
\end{array}\right.
$$

where the value of the $T H I_{\text {Threshold }}$ was set to 72 as proposed by Ravagnolo et al. (2000). This threshold corresponds to conditions equivalent to $22^{\circ} \mathrm{C}$ at $100 \%$ humidity.
The following multiple-trait random regression model (Aguilar et al., 2009) was used for the genetic evaluation:

$$
\begin{aligned}
y_{i j k l t}= & \text { fixed }_{i t} \\
& +\sum_{q=1}^{4} \alpha_{q}(D I M) a_{q j t}+\varphi(T H I) a_{5 j t} \\
& +\sum_{q=1}^{4} \alpha_{q}(D I M) p_{q j t}+\varphi(T H I) p_{5 j t} \\
& +\sum_{q=1}^{4} \alpha_{q}(D I M) h_{q k t}+\varphi(T H I) h_{5 k t}+e_{i j k l t},
\end{aligned}
$$

where $y_{i j k l t}$ is the $l$ th test day of cow $j$, and th parity in $k$ th herd-year at the ith combination of fixed effects within the $t$ trait. Fixed effects included herd test-day effect within parity with 2,603,783 $(2,153,285$; $1,749,619)$ levels for first (second; third) parity; the DIM class effect within season (124 levels, 4 seasons defined from December to February, March to May, June to August, and September to November, and 31 classes for DIM starting from 5 up to 305 DIM with classes defined every $10 \mathrm{~d}$ ); the calving age class effect within parity with $8(11 ; 12)$ levels for first (second; third) parity; and the milking frequency class effect (2 or 3 milkings per day). Random effects (levels) included $a$, additive genetic $(9,326,754), p$, permanent environment $(5,402,484)$, and $h$, herd-year $(264,045)$ and were fitted as random regression. Covariates included linear splines $(\alpha)$ with 4 knots at 5, 50, 200, and 305 DIM and the function of THI (heat-stress effect). Finally, $e_{i j k l t}$ is the random residual effect. The first 3 lactations were used as separate traits.

The (co)variance structure was

$$
V\left[\begin{array}{c}
\mathbf{a} \\
\mathbf{p} \\
\mathbf{h} \\
\mathbf{e}
\end{array}\right]=\left[\begin{array}{cccc}
\mathbf{A} \otimes \mathbf{G}_{o} & 0 & 0 & 0 \\
& \mathbf{I} \otimes \mathbf{P}_{o} & 0 & 0 \\
& & \mathbf{I} \otimes \mathbf{H}_{o} & 0 \\
\text { symm } & & & \mathbf{I} \otimes \mathbf{R}_{o}
\end{array}\right]
$$



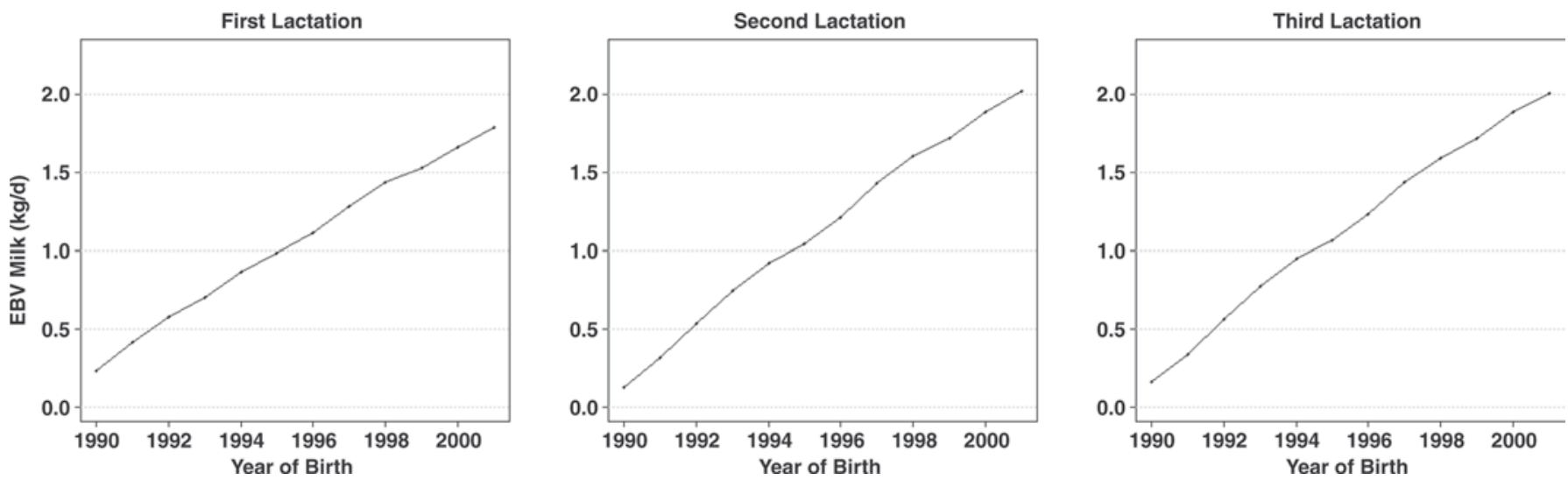

Figure 1. Genetic trends of daily milk yield for each lactation.

where $\mathbf{G}_{o}, \mathbf{P}_{o}$, and $\mathbf{H}_{o}$ were $15 \times 15$ (co)variance matrices for additive genetic, permanent, and herd-year effects, respectively, $\mathbf{A}$ was an additive relationship matrix, $\mathbf{I}$ was an identity matrix, and $\mathbf{R}_{o}$ was a $3 \times 3$ diagonal matrix of residual variance corresponding to each trait (parity). Genetic parameters used were from Aguilar et al. (2009).

Solutions for mixed model equations were obtained iteratively using the preconditioned conjugate gradient algorithm implemented in BLUP90IOD (Tsuruta et al., 2001), modified for a block diagonal preconditioner due to traits and random correlated effects to improve the convergence rate (Aguilar et al., 2010). The convergence criterion $(\mathrm{C})$ was based on the relative adjusted right-hand side and the iterations were stopped when $\mathrm{C}<10^{-12}$.

Genetic trends were calculated for daily milk yield in absence of heat stress, herein called the regular effect, and for the daily heat stress effect on milk yield at $5^{\circ} \mathrm{C}$ over the threshold (Figures 1 and 2, respectively). Genetic trends for the regular effect were $0.140 \mathrm{~kg} / \mathrm{yr}$, $0.172 \mathrm{~kg} / \mathrm{yr}$, and $0.168 \mathrm{~kg} / \mathrm{yr}$ for first, second, and third parity, respectively. The genetic trend for heat-stress effect in first lactation was almost null $(-0.002 \mathrm{~kg} / \mathrm{yr})$; however, in later lactations these trends were negative, $-0.035 \mathrm{~kg} / \mathrm{yr}$ for second parity, and $-0.038 \mathrm{~kg} / \mathrm{yr}$ for third parity. The absence of the trend for heat stress in the first parity could be because of a smaller sensitivity to heat stress in first-parity cows due to lower production and the compensatory effect of selection for nonproduction traits such as type, productive life, and daughter pregnancy rate. In later lactations, the sensitivity to heat stress increases and cannot be fully compensated.

Assuming a $100 \mathrm{~d} / \mathrm{yr}$ heat stress at $5^{\circ} \mathrm{C}$ over the threshold, the trend on a lactation basis would be -0.2 $\mathrm{kg}$ for the first parity, $-3.5 \mathrm{~kg}$ for the second parity, and $-3.8 \mathrm{~kg}$ for the third parity. These numbers cor-
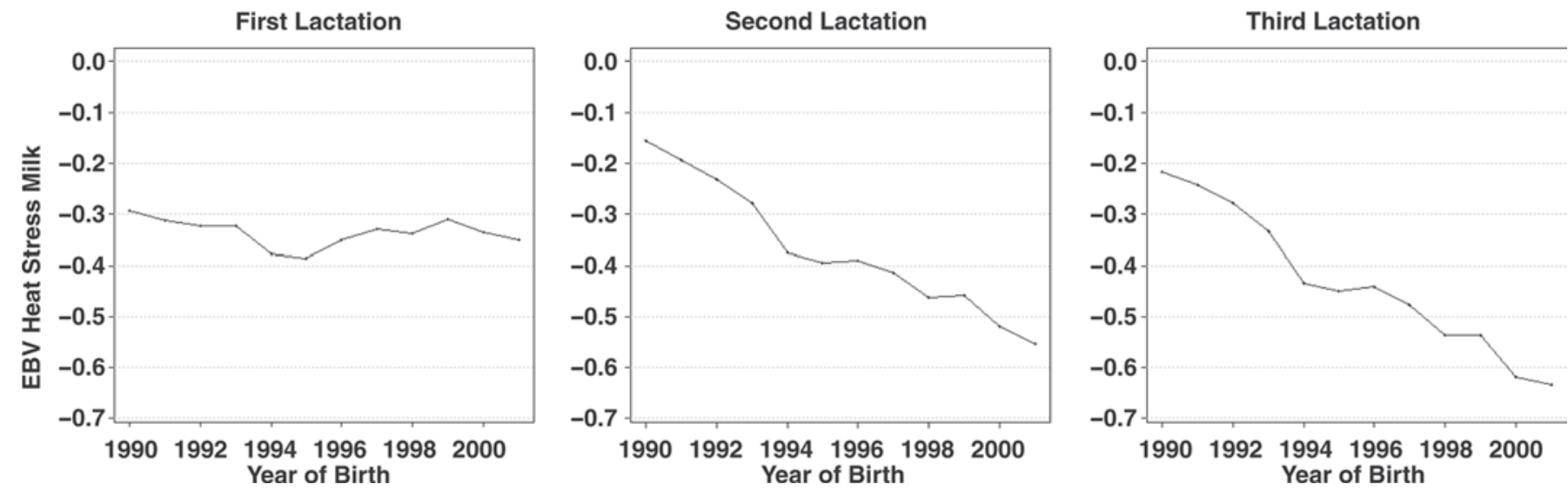

Figure 2. Genetic trends of daily heat stress effect at $5^{\circ} \mathrm{C}$ over the threshold for each lactation. 
Table 2. Difference between PTA and type performance index (TPI) from February 2005 US official evaluation for the 100 most heat-tolerant and 100 least heat-tolerant sires in separate lactations

\begin{tabular}{|c|c|c|c|}
\hline \multirow[b]{2}{*}{ Item } & \multicolumn{3}{|c|}{$\begin{array}{l}\text { Difference between most heat- } \\
\text { tolerant and least heat-tolerant }\end{array}$} \\
\hline & First $^{1}$ & Second & Third \\
\hline Milk $(\mathrm{kg})^{2}$ & -705 & -827 & -710 \\
\hline Fat $(\mathrm{kg})^{2}$ & -10 & -16 & -13 \\
\hline Protein $(\mathrm{kg})^{2}$ & -14 & -18 & -15 \\
\hline Fat $(\%)^{2}$ & 0.14 & 0.12 & 0.11 \\
\hline Protein $(\%)^{2}$ & 0.07 & 0.06 & 0.05 \\
\hline Type $^{3}$ & 0.49 & 0.16 & 0.23 \\
\hline Udder composite $^{3}$ & 1.18 & 0.71 & 0.54 \\
\hline Feet and leg composite ${ }^{3}$ & 0.51 & 0.08 & 0.02 \\
\hline Body composite ${ }^{3}$ & 0.18 & 0.15 & 0.50 \\
\hline Dairy composite $^{3}$ & -0.94 & -1.14 & -0.53 \\
\hline Stature $^{3}$ & 0.14 & 0.14 & 0.49 \\
\hline Strength $^{3}$ & 0.36 & 0.30 & 0.63 \\
\hline Body depth ${ }^{3}$ & -0.02 & -0.05 & 0.30 \\
\hline Dairy form ${ }^{3}$ & -1.54 & -1.78 & -1.24 \\
\hline Rump angle $^{3}$ & -0.56 & -0.28 & 0.01 \\
\hline Thurl width $^{3}$ & 0.20 & 0.18 & 0.50 \\
\hline Leg side view ${ }^{3}$ & -0.49 & -0.31 & 0.09 \\
\hline Rear leg rear view ${ }^{3}$ & 0.01 & -0.48 & -0.31 \\
\hline Foot angle ${ }^{3}$ & 0.62 & 0.20 & 0.15 \\
\hline Feet and leg score ${ }^{3}$ & 0.63 & 0.21 & 0.06 \\
\hline Fore udder attachment ${ }^{3}$ & 1.20 & 0.73 & 0.56 \\
\hline Rear udder height $^{3}$ & 0.75 & 0.14 & 0.18 \\
\hline Rear udder width ${ }^{3}$ & 0.35 & -0.14 & -0.01 \\
\hline${\text { Udder } \text { cleft }^{3}}^{3}$ & 1.14 & 0.65 & 0.48 \\
\hline Udder depth ${ }^{3}$ & 2.02 & 1.58 & 1.16 \\
\hline Front teat placement ${ }^{3}$ & 0.66 & 0.31 & 0.20 \\
\hline Teat length ${ }^{3}$ & -0.33 & -0.28 & -0.13 \\
\hline $\mathrm{TPI}^{2}$ & -23 & -183 & -163 \\
\hline Net merit ${ }^{2}$ & -67 & -173 & -170 \\
\hline Fluid merit ${ }^{2}$ & -124 & -225 & -216 \\
\hline Cheese merit $^{2}$ & -35 & -145 & -145 \\
\hline Productive life $^{2}$ & 1.48 & 1.20 & 0.64 \\
\hline $\mathrm{SCS}^{2}$ & -0.13 & -0.12 & -0.08 \\
\hline Daughter pregnancy rate $^{2}$ & 1.64 & 1.94 & 1.45 \\
\hline Daughter calving ease ${ }^{2}$ & -0.11 & -0.44 & -0.17 \\
\hline
\end{tabular}

respond to a reduction in milk at $5{ }^{\circ} \mathrm{C}$ relative to milk at no heat stress. Higher and longer levels of heat stress would reduce milk further.

Although the trends for heat-stress effect appear small, they are underestimated. Freitas et al. (2006) found that the use of only test-day records over time captured a small fraction of the response due to heat stress compared with daily records. Thus, the real decline due to heat stress may be as large as the gain during temperate periods. Bohmanova et al. (2008) investigated whether the differences in bull rankings from US regional genetic evaluations in the Southeast and the Northeast were caused by heat stress. Although some of the differences were accounted for by the effect of heat stress in the model, most of those differences were not accounted for because of limitations of the model and the data. Although the decline in milk under high temperatures may be compensated for by an increase of overall production, the decline might be economically more important if it involves traits correlated with milk. Findings by Pszczola et al. (2009) show that the trend of the heat stress component of days open is also negative. Thus, they are an indication that the selection against heat tolerance occurs for a variety of economically important traits. Also, the economic effect of heat stress may be larger than that measured by milk yield only; for example, because of reduced fertility (Jordan, 2003) and increased mortality (Ely and Smith, 2004; Stull et al., 2008).

Official proofs from the February 2005 US Holstein genetic evaluation were used to calculate profiles of PTA and type performance index (TPI) (Table 2). For each 
parity, based on the breeding value of the heat-stress effect, the 100 most heat-tolerant and 100 least heattolerant bulls with at least 50 daughters were grouped, and the averages of the official proofs were calculated. The differences in the first parity were similar to those reported by Bohmanova et al. (2005) and indicate that the most heat-tolerant sires transmit lower production and dairy form but higher fertility, productive life, and type, especially udder and locomotion traits. In later parities, the advantages for type are reduced.

The differences are similar between parities for most of the traits. In particular, differences increase for stature and strength and decrease for productive life. High stature and strength may indicate a more robust cow that is more able to handle the heat stress especially that larger cows have more surface area and can dissipate more heat. Lower advantage for productive life, especially for the third parity, may indicate that this trait reflects primarily survival in the first 2 parities but less in the third one.

In conclusion, studies on genetics of heat stress should include records of later parities because these are more susceptible to heat stress and therefore more informative than records in the first parity. Lack of records from later parities may be the reason for inconclusive results in the study by Bohmanova et al. (2008). In addition, Holsteins are selected against heat tolerance, and therefore their profitability in areas under heat stress may deteriorate over time. A more detailed account of the effect of heat stress on overall profitability may require multi-trait models in which the information on culling is included.

\section{ACKNOWLEDGMENTS}

The authors thank J. B. Cole from Animal Improvement Programs Laboratory, ARS, USDA (Beltsville, MD) for providing the production and weather data. This study was supported by the Holstein Association USA Inc. (Brattleboro, VT) and by a grant from ARS, USDA.

\section{REFERENCES}

Aguilar, I., I. Misztal, and S. Tsuruta. 2009. Genetic components of heat stress for dairy cattle with multiple lactations. J. Dairy Sci. 92:5702-5711.

Aguilar, I., S. Tsuruta, and I. Misztal. 2010. Computing options for multiple-trait test-day random regression models while accounting for heat tolerance. J. Anim. Breed. Genet. doi:10.1111/j.1439$0388.2009 .00842 . \mathrm{x}$

Bohmanova, J., I. Misztal, S. Tsuruta, H. D. Norman, and T. J. Lawlor. 2005. National genetic evaluation of milk yield for heat tolerance of United States Holsteins. Interbull Bull. 33:160-162.

Bohmanova, J., I. Misztal, S. Tsuruta, H. D. Norman, and T. J Lawlor. 2008. Short communication: Genotype by environment interaction due to heat stress. J. Dairy Sci. 91:840-846.

Bryant, J. R., N. Lopez-Villalobos, J. E. Pryce, C. W. Holmes, D. L. Johnson, and D. J. Garrick. 2007. Environmental sensitivity in New Zealand dairy cattle. J. Dairy Sci. 90:1538-1547.

Ely, L. O., and J. W. Smith. 2004. Factors affecting death losses in DHI Holstein herds. J. Dairy Sci. 87(Suppl. 1):228-229. (Abstr.)

Freitas, M. S., I. Misztal, J. Bohmanova, and J. West. 2006. Utility of on- and off-farm weather records for studies in genetics of heat tolerance. Livest. Sci. 105:223-228.

Fuquay, J. W. 1981. Heat stress as it affects animal production. J. Anim. Sci. 52:164-174

Garcia-Ispierto, I., F. Lopez-Gatius, G. Bech-Sabat, P. Santolaria, J. L. Yaniz, C. Nogareda, F. De Rensis, and M. Lopez-Bejar. 2007. Climate factors affecting conception rate of high producing dairy cows in northeastern Spain. Theriogenology 67:1379-1385.

Jordan, E. R. 2003. Effects of heat stress on reproduction. J. Dairy Sci. 86(E. Suppl.):E104-E114.

Kadzere, C. T., M. R. Murphy, N. Silanikove, and E. Maltz. 2002 Heat stress in lactating dairy cows: A review. Livest. Prod. Sci 77:59-91.

Maust, L. E., R. E. MacDowell, and N. W. Hooven. 1972. Effect of summer weather on performance of Holstein cows in three stages of lactation. J. Dairy Sci. 55:1133-1139.

NOAA (National Oceanic and Atmospheric Administration). 1976 Livestock hot weather stress. U.S. Department of Commerce. National Weather Service Central Region. Regional Operations Manual Letter C-31-76., Kansas City, MO.

Pszczola, M., I. Aguilar, and I. Misztal. 2009. Short communication: Trends for monthly changes in days open in Holsteins. J. Dairy Sci. 92:4689-4696.

Ravagnolo, O., and I. Misztal. 2000. Genetic component of heat stress in dairy cattle, parameter estimation. J. Dairy Sci. 83:21262130.

Ravagnolo, O., and I. Misztal. 2002. Effect of heat stress on nonreturn rate in Holstein cows: Genetic analyses. J. Dairy Sci. 85:30923100

Ravagnolo, O., I. Misztal, and G. Hoogenboom. 2000. Genetic component of heat stress in dairy cattle, development of heat index function. J. Dairy Sci. 83:2120-2125.

St-Pierre, N. R., B. Cobanov, and G. Schnitkey. 2003. Economic losses from heat stress by US livestock industries. J. Dairy Sci. 86(E Suppl.):E52-E77.

Stull, C. L., L. L. McV. Messam, C. A. Collar, N. G. Peterson, A. R Castillo, B. A. Reed, K. L. Andersen, and W. R. VerBoort. 2008 Precipitation and temperature effects on mortality and lactation parameters of dairy cattle in California. J. Dairy Sci. 91:45794591.

Tsuruta, S., I. Misztal, and I. Stranden. 2001. Use of the preconditioned conjugate gradient algorithm as a generic solver for mixed-model equations in animal breeding applications. J. Anim. Sci. 79:11661172

West, J. W. 2003. Effects of heat-stress on production in dairy cattle. J. Dairy Sci. 86:2131-2144. 